\title{
Sustainable Local Development in Romania in the Opportunity of Creating Jobs
}

\author{
By Florina Bran ${ }^{1}$, Ghenadie Ciobanu ${ }^{2}$, Maria Loredana Popescu ${ }^{3}$, \\ Petrut Cristian Vasilache ${ }^{4}$
}

\begin{abstract}
The economic, social transformations of the last three decades of evolution of rural development both in Romania and in general in rural areas in the context of globalization have radically changed the vision, thinking and attitude of the rural population. As a result, it has led to a massive migration of population to other developed countries. This phenomenon is also characteristic for Romania. At the same time, the technological development has a massive impact on the process of organizing the society and the evolution of the society, both the evolution of biotechnologies, nanotechnologies, branches in the field of chemistry, biochemistry and digitization, which have impact on the development or underdevelopment of the areas in poverty and underdevelopment. economic, but at the same time they will be able to make an essential contribution to the local rural development and to the creation of new job opportunities for both young people and specialists from different branches, as well as for vulnerable groups of population from the rural area. In this article we aim to address these issues and come up with certain solutions and proposals.
\end{abstract}

Keywords: Sustainable local development, rural areas, technological development, digitization

\section{Introduction}

The objectives of the „EU sustainable development strategy including an environmental dimension (Rădulescu et al., 2018). This recognizes that in the long term, economic growth, social cohesion and environmental protection must go hand in hand. Sustainable development offers the European Union a positive long-term vision of a society" (Angheluta et al., 2019). Therefore, the growth of the economy supports the social progress and respects the environment, the social policy is based on economic and political environmental performance is profitable (Dima et al., 2020). Decoupling environmental degradation and resource consumption necessary for economic and social management or reorienting public and private investigations to green technologies. (Seghezzo, 2009)

According to the 2020 Strategy (2011): „Sustainable growth implies the construction of a competitive, sustainable and efficient economy from the point of view of the use of resources, for the development of new processes and technologies, of the ecological technologies, the acceleration of the development of intelligent networks, which reinforces the competitive advantage of the business environment, in the production sectors and within SMEs and help consumers realize the merits of efficient use of 
resources (Bodislav et al., 2019).

The implementation of Local Agenda 21 in Romania began, with the support of UNDP, in 2000 year and has so far included 38 municipalities, cities and 4 counties. The aim of this project was to strengthen the operational capacity needed for local authorities.

A study at national level on the current situation regarding green jobs in Romania, which addressed the issue in our country is "Green Jobs - Creating a system for analyzing and monitoring green jobs in Romania". In this study, a documentary research was carried out to identify the initiatives regarding the transition to a green economy at national level, of the statistics available in the field, as well as of the existing measures, which are already or could be used to promote green jobs (Costache et al., 2015). Proposals were made regarding the possible definition of the green workplace, but also others, general as well as institutional, to contribute to the implementation of the concept of green workplace at the level of the Public Employment Services in Romania.

\section{Evolution of the Macroeconomic Indicators in the Context of the Labor Market}

Romania as a member country of the EU owns 5.41\% of the surface of EU 27, with a territory comprising 5 bio-geographical regions (steppe, pontic, panonic, continental and alpine): $33 \%$ plain area. 37\% hilly area and 30\% mountain area, about $87.1 \%$ represent the rural area. Romania is divided into 8 development regions (NUTS II), with an average population of 2.67 million inhabitants per region; 42 counties, reflecting the administrative-territorial structure of the country (NUTS III); 320 municipalities and cities, 2,861 communes with 12,957 villages (NUTS V) (Statistical Yearbook, 2012) (Cabiddu \& Pettinao, 2012). At the level of the eight regions in Romania we intend to go in retrospect the situation regarding the economic growth. The GDP of the South Muntenia region exceeds the GDP of the North-West region in which the city of Cluj enters, this difference in development is explained by the fact that in the South Muntenia region there are two important economic agents Renault Dacia and OMV Petrom.

a) GDP forecast for Romania

Chart 1. GDP forecast for Romania in the period 2018 - 2023 made by the National Forecast Commission - percentage changes compared to the previous year, $\%$ -

\begin{tabular}{|l|c|c|c|c|c|c|}
\hline & 2018 & 2019 & 2020 & 2021 & 2022 & 2023 \\
\hline Total economy & & & & & & \\
\hline The gross domestic product & 4,1 & 4 & 4,1 & 4,2 & 4,2 & 4 \\
\hline of which, the gross value added in: & & & & & & \\
\hline industry & 4,1 & $-1,3$ & 2,9 & 3,1 & 3,3 & 2,9 \\
\hline agriculture & 10 & -5 & 2,5 & 1,1 & 1,1 & 1,1 \\
\hline construction & $-5,6$ & 15,5 & 6,2 & 7 & 7,2 & 6,8 \\
\hline services & 3,6 & 4,8 & 4,2 & 4,5 & 4,5 & 4,3 \\
\hline
\end{tabular}

Source: National Commission for Strategy and Prognosis http:// www.cmp.ro/en/prognoze

From this table (Chart 1) we notice that GDP growth will average 4\%, of which in industry it will be 3.1 in 2021, 3.3 in 2022, and 2.9 in 2023, in agriculture of 2.5 in 2020, 
1.1 in 2021 and 2022-2023. A big increase will be in constructions, in 2019 of 15.5\%, $6.2 \%$ in 2020, in 2023 of $6.8 \%$, respectively the services from 4.8 in 2019, which are maintained at 4.5 in 2020/2021 and 4.3 in 2023. We are interested in the forecast for the development regions, presented below in chart 2 .

Chart 2. GDP forecast by development regions in the period 2018-2023 (\%)

\begin{tabular}{|l|c|c|c|c|c|c|}
\hline Development regions & $\mathbf{2 0 1 8}$ & $\mathbf{2 0 1 9}$ & $\mathbf{2 0 2 0}$ & $\mathbf{2 0 2 1}$ & $\mathbf{2 0 2 2}$ & $\mathbf{2 0 2 3}$ \\
\hline North East & 4,3 & 5,3 & 4,6 & 4,7 & 4,8 & 4,6 \\
\hline South East & 4,4 & 4 & 4,3 & 4,3 & 4,3 & 4,1 \\
\hline South Muntenia & 5,2 & 3,1 & 4,3 & 4,3 & 4,4 & 4,2 \\
\hline South West Oltenia & 5,8 & 3,4 & 4,4 & 4,5 & 4,7 & 4,4 \\
\hline northwest & 4,3 & 5,3 & 4,4 & 4,5 & 4,5 & 4,3 \\
\hline West & 2,8 & 2,9 & 4,2 & 4,2 & 4,3 & 4,2 \\
\hline Center & 4,9 & 4,1 & 4,6 & 4,6 & 4,7 & 4,4 \\
\hline Bucharest-Ilfov & 3 & 3,7 & 3,4 & 3,6 & 3,5 & 3,2 \\
\hline
\end{tabular}

Source: National Commission for Strategy and Prognosis, bttp://wmw.cnp.ro/en/prognoze

Labor migration from the regions of Romania, especially from the rural areas is one of the main problems.

b) Migration. Labor migration from the regions of Romania, especially from the rural areas is one of the main problems.

Chart 3. Definitive emigrants by gender, macro-regions, development regions and departure counties

\begin{tabular}{|l|c|c|c|c|c|c|c|c|c|c|c|}
\hline Chart 3. & 1990 & 1991 & 1994 & 1997 & 2000 & 2003 & 2006 & 2009 & 2012 & 2015 & 2018 \\
\hline Total & 96929 & 44160 & 17146 & 19945 & 14753 & 10673 & 14197 & 10211 & 18001 & 15235 & 27229 \\
\hline North-West & 11296 & 6754 & 2532 & 3003 & 2271 & 1893 & 1876 & 1284 & 1766 & 1831 & 2896 \\
\hline Centre & 39681 & 15907 & 3819 & 4071 & 2640 & 2219 & 2739 & 1689 & 1776 & 1794 & 3043 \\
\hline North-East & 1761 & 1949 & 711 & 1596 & 1837 & 1495 & 2556 & 1593 & 3027 & 2729 & 5486 \\
\hline South-East & 1648 & 1776 & 778 & 1202 & 1213 & 826 & 1360 & 1038 & 1620 & 1823 & 3639 \\
\hline South-Muntenia & 1204 & 2188 & 540 & 971 & 1039 & 538 & 663 & 644 & 1414 & 1590 & 2816 \\
\hline Bucharest-Ilfov & 7977 & 4032 & 3678 & 4045 & 2913 & 1792 & 2440 & 1936 & 5479 & 2705 & 4549 \\
\hline Ilfov & 199 & 101 & 99 & 66 & 52 & 34 & 37 & 50 & 57 & 174 & 305 \\
\hline Bucharest & 7778 & 3931 & 3579 & 3979 & 2861 & 1758 & 2403 & 1886 & 5422 & 2531 & 4244 \\
\hline South-West Oltenia & 827 & 1040 & 396 & 835 & 772 & 489 & 617 & 607 & 791 & 833 & 1470 \\
\hline West & 32535 & 10514 & 4692 & 4222 & 2068 & 1421 & 1946 & 1420 & 2128 & 1930 & 3330 \\
\hline Men, total & 46335 & 21211 & 7886 & 9423 & 6798 & 4413 & 5341 & 3768 & 8174 & 6521 & 11989 \\
\hline Women, total & 50594 & 22949 & 9260 & 10522 & 7955 & 6260 & 8856 & 6443 & 9827 & 8714 & 15240 \\
\hline
\end{tabular}

Source: www.insse.ro/ Definitive emigrants by gender, macro-regions, development regions and departure counties

From 96.929 emigrants in 1990, to 27.229 in 2018. Of which - from 46.335 men in 1990 it decreased to 11.989 in 2018, from 50.594 women in 1990 to 15.240 in 2018. By regions, the situation is as follows, if in 1990 the largest number of emigrants from the Center region is 39.681, in the second place is the West Region with 32.535. The fewest who have emigrated are from South-West Oltenia Region with 827 people, SouthMuntenia with 1.204 people and South-East with 1.648 people. In 2018 we have the 
following situation, the largest number of emigrants is 5.486 people in the North-East region, on the second place is the municipality of Bucharest with a number of 4.549 people. At least 1.470 people migrated from the South-West Oltenia Region and the South-Muntenia Region with 2,816 people.

c) Labor market evolution. In addition to this phenomenon, the local authorities in Romania are facing various local problems of underdevelopment, of the deficit of food sources, water, energy, deterioration of the environment, drug use and so on (Ionita et al., 2009). For these reasons we present below:

Chart 4. Evolution of the unemployment rate in Romania between 1992-2018

\begin{tabular}{|l|c|c|c|c|c|c|c|c|c|c|c|c|c|c|}
\hline & 1992 & 1994 & 1996 & 1998 & 2000 & 2002 & 2004 & 2006 & 2008 & 2010 & 2012 & 2014 & 2016 & 2018 \\
\hline Total & 8,2 & 10,9 & 6,6 & 10,4 & 10,5 & 8,4 & 6,3 & 5,2 & 4,4 & 7 & 5,4 & 5,4 & 4,8 & 3,3 \\
\hline Men & 6,2 & 9 & 5,7 & 10,4 & 10,7 & 8,9 & 7 & 5,7 & 4,4 & 7,6 & 5,9 & 5,9 & 5,1 & 3,4 \\
\hline Women & 10,3 & 12,9 & 7,5 & 10,4 & 10,1 & 7,8 & 5,6 & 4,6 & 4,4 & 6,3 & 4,9 & 4,8 & 4,4 & 3,3 \\
\hline
\end{tabular}

Source: www.insse.rol

From this chart we observe that during the period 1992-2018 unemployment has evolved differently. In $1992-8.2 \%, 1994-10.9 \%$, with a decrease in the next period to $6.6 \%$ in 1996 and a return in 1998-2000 to $10.4-10.5 \%$ and in 2004-2018 with a gradual decrease from $6.3 \%$ in 2004 to $3.3 \%$ in 2018; with the same proportional tendency in men (in 2004 from $7 \%$ up to $3.4 \%$ in 2018) and in women from $5.6 \%$ in 2004 to $3.3 \%$ in 2018. By 1998 unemployment had more impact on women than men, on women in 1992 - $10.3 \%$ compared to $6.2 \%$ on men. In 1994 , women had a rate of $12.9 \%$, while men $9 \%$. In 1998 the rates are equalized between women and men, reaching 10.4\% total unemployment rate. After 1998, the highest share of unemployed men in 2000 is $10.7 \%$, in $2002,8.9 \%$ for men and $7.8 \%$ for women. We would like to mention that in Romania unemployment has not manifested itself with special developments; most of the unemployment is represented by long-term unemployment, due to the reduced capacity of the economy to create jobs, the rigidity of the labor market, which has contributed to preventing the harmonization of supply and demand (Burlacu et al., 2019). However, we must mention that the labor market is at an imbalance due to the shortage of human resources in certain branches of the economy.

Chart 5. Unemployment evolution by development regions (\%)

\begin{tabular}{|l|c|c|c|c|c|c|c|c|c|c|c|c|c|c|}
\hline & 1992 & 1994 & 1996 & 1998 & 2000 & 2002 & 2004 & 2006 & 2008 & 2010 & 2012 & 2014 & 2016 & 2018 \\
\hline North-West & 8,9 & 10,1 & 5,6 & 8,8 & 8,5 & 6,8 & 4,2 & 3,6 & 3,3 & 5,9 & 4,4 & 3,8 & 3,2 & 2,3 \\
\hline Centre & 6,8 & 10 & 6,1 & 10,2 & 10,3 & 9 & 7,8 & 6,1 & 5,2 & 8 & 6,2 & 5,5 & 4,4 & 2,9 \\
\hline North-East & 11,4 & 16,4 & 10 & 13,9 & 13,2 & 10,8 & 7,8 & 6,2 & 5,3 & 7,8 & 6 & 6,6 & 6,5 & 4,8 \\
\hline South-East & 10,4 & 11,9 & 7,4 & 11,7 & 11,4 & 10 & 6,9 & 5,6 & 4,7 & 8,1 & 6,4 & 6,9 & 6,7 & 4,6 \\
\hline South-Muntenia & 6,6 & 9,9 & 5,6 & 10,1 & 10,4 & 9,2 & 7,4 & 6,4 & 5,2 & 8,8 & 6,9 & 7,3 & 6,3 & 4 \\
\hline Bucharest-Ilfov & 4,8 & 5,7 & 3,4 & 4,9 & 5,8 & 3,3 & 2,8 & 2,2 & 1,6 & 2,4 & 2 & 1,9 & 1,5 & 1,2 \\
\hline Ilfov & $:$ & $:$ & $:$ & 4,6 & 6,2 & 5,4 & 4,1 & 1,9 & 1,3 & 2,7 & 1,8 & 1,5 & 1 & 0,6 \\
\hline Bucharest & $:$ & $:$ & $:$ & 5 & 5,7 & 3 & 2,6 & 2,2 & 1,6 & 2,3 & 2 & 2 & 1,6 & 1,3 \\
\hline South-West Oltenia & 8 & 11 & 6,5 & 10,9 & 11,6 & 9,4 & 7,5 & 7 & 6,9 & 9,2 & 8,2 & 8,2 & 8,3 & 5,9 \\
\hline West & 6,8 & 9,2 & 5,9 & 10,6 & 10,4 & 6,6 & 5,8 & 4,1 & 3,8 & 5,9 & 3,9 & 3,4 & 2,6 & 1,8 \\
\hline
\end{tabular}

Source: wmw.insse.rol 
In the regions of development, the next evolution of unemployment is in the NorthWest region from 8.9\% in 1992, to 10.1 in 1994, with a decrease to 5.6 in 1996 and a return to $8.8 \%$ in 1998. In the Center region from 6.8\% in 1992, to $10 \%$ in 1994, 10.2 in 1998 to 10.3 in 2000 with a gradual fall from $9 \%$ in 2002, to 5.2 in 2008 and during the period 2012-2018, a decrease from $6.2 \%$ to $2.9 \%$ in 2018. Situations with similar approximation are observed in the North-East and South-East regions in 1992 from $11.4 \%$ in North-East, 10.4\% in South-East in 2018, respectively 4.8\% in North-East and $4.6 \%$ in the South-East region. The South-Muntenia region registered 6.6\% in 1992, and in $4 \%$ in 2018. South-West Oltenia from $8 \%$ in 1992, down to 5.9 in 2018, although in 2010-9.2\%, $2012-8.2 \%, 2014-8.2 \%$ and $2016-8.3 \%$ we observe higher records. We have a good position in the Bucharest Ilfov Region and in the West Region. In 1992 Bucharest Ilfov region registered an unemployment rate of $4.8 \%$, and in recent years, in $2014-1.9 \%, 2016-1.5 \%$ and in 2018-1.2\%. In the West Region we have an evolution from $6.8 \%$ in 1992 , with a gradual evolution in the last years of $3.4 \%$ in $2014,2.6 \%$ in 2016 , and $1.8 \%$ in 2018.

Chart 6. Rate of risk of poverty or social exclusion, by development regions

\begin{tabular}{|l|c|c|c|c|c|c|c|c|c|c|c|c|}
\hline Regions & $\mathbf{2 0 0 7}$ & $\mathbf{2 0 0 8}$ & $\mathbf{2 0 0 9}$ & $\mathbf{2 0 1 0}$ & $\mathbf{2 0 1 1}$ & $\mathbf{2 0 1 2}$ & $\mathbf{2 0 1 3}$ & $\mathbf{2 0 1 4}$ & $\mathbf{2 0 1 5}$ & $\mathbf{2 0 1 6}$ & $\mathbf{2 0 1 7}$ & $\mathbf{2 0 1 8}$ \\
\hline Total & 47 & 44,2 & 43 & 41,5 & 40,9 & 43,2 & 41,9 & 40,3 & 37,4 & 38,8 & 35,7 & 32,5 \\
\hline North-West & 39,2 & 34,9 & 36,2 & 32,1 & 35,2 & 33,5 & 32,3 & 32,1 & 28 & 29,3 & 26,4 & 22,3 \\
\hline Centre & 39,5 & 39 & 33,3 & 31,3 & 30,6 & 34,3 & 36 & 35,7 & 31,6 & 29,5 & 25,7 & 24,4 \\
\hline North-East & 56,7 & 55,5 & 52,9 & 52,4 & 51,7 & 52,1 & 51,5 & 49,4 & 46,3 & 46 & 43,9 & 44,7 \\
\hline South-East & 52,9 & 46,7 & 42,6 & 51,7 & 49,6 & 54,1 & 53,9 & 53,2 & 46,2 & 44,9 & 42,5 & 40,3 \\
\hline South-Muntenia & 52 & 46 & 47,6 & 42,8 & 43,5 & 45,5 & 42 & 41,7 & 43,5 & 41,2 & 40,9 & 36,3 \\
\hline Bucharest - Ilfov & 37,3 & 34 & 40,3 & 32,7 & 29,7 & 31,4 & 30,7 & 25,1 & 20,5 & 32,9 & 25 & 21,4 \\
\hline South-West Oltenia & 57 & 56,6 & 53,2 & 47,5 & 45,8 & 48,4 & 44,6 & 40,9 & 41,9 & 44,2 & 45,3 & 42,2 \\
\hline West & 33 & 34,3 & 31,8 & 36,2 & 34,6 & 41,7 & 40,4 & 40,1 & 32 & 40,7 & 32,5 & 22,1 \\
\hline
\end{tabular}

Source: www.insse.rol

The poverty risk rate decreased from $47 \%$ in 2007 to $32.5 \%$ in 2018 . We note that the highest risk comes from the North-East region from $56.7 \%$ in 2007 , to $44.7 \%$ in 2018 , followed by South-East region from 52.9\% in 2007 to $40.3 \%$ in 2018. Another region of risk is South-West Oltenia from $57 \%$ in 2007 , to $42.2 \%$ in 2018 . The lowest risk is in Bucharest-Ilfov regions - 21.4\%, West region with $22.1 \%$, North-West region with $22.3 \%$ and Center with $24.4 \%$.

How and to what extent can sustainable development contribute to solving the problems listed above?

\section{Strategic Objectives on the Sustainable Development of Romania}

According to the Sustainable Development Strategy of Romania 2030, Romania needs to change the current paradigm of development in order to face the challenges of the 21 st century, in the age of globalization, increasing inequalities and increasing environmental degradation. Therefore, the solution is sustainable development. Romania's Sustainable Development Strategy takes on the challenge and tries to help Romania go through the transition to a sustainable future. Based on the principles of the 
2030 Agenda for sustainable development, this transition will be achieved as a member of the European Union. In the international context of sustainable development Agenda 2030 was the result of an extensive process of international analysis that recognizes that global problems can only be solved through global solutions (Burlacu et al., 2018). A change in the perception and an increasing awareness of the unprecedented development of human society, the increase of the global birth rate, the rapid growth of the economies of the developing countries and the increase of the social disparity have highlighted the limits of the global growth.

The objectives of sustainable development, it pursues the following objectives: (1) Ensuring universal access to information, education and counseling services to encourage the prevention and adoption of a healthy lifestyle. (2) Ensuring complete digitization of the health system and implicitly eliminating printed documents and records, to increase the efficiency and facilitation of medical interventions, thus ensuring the rapid access of the population to quality medical services, treatment, medicines and efficient monitoring of needs. (3) Reduces the prevalence of maternal and infant mortality and the incidence of breast and cervical cancer and adolescent pregnancies, with the main focus on vulnerable and disadvantaged groups (4) Reducing maternal mortality and neonatal mortality to the lower EU average. (5) Increase vaccine coverage to the minimum level recommended by WHO for each vaccine by developing a common platform of collaboration between authorities, physicians, patients, international organizations with experience in the field, (6) Promoting awareness of mental illness, reducing the associated stigma and creating an environment in which those suffering from mental illness feel accepted and can ask for help. (7) Eliminates tuberculosis contraction and the fight against hepatitis and other communicable diseases. (8) Reduction by one third of the number of premature deaths due to noncommunicable diseases through prevention and treatment and by promoting mental health and well-being (9) Reducing mortality from chronic diseases (10) Reducing the level of consumption of toxic substances.

A special place belongs to Education for Sustainable Development, according to UNESCO; education for sustainable development is "a key tool for achieving the SDGs". Sustainable development is a paradigm based on ethics and education for sustainable development and aims to develop competences that allow individuals to reflect on their own actions, taking into account the current, future social, cultural, economic and environmental impact. According to the study in the first decade of the implementation of the National Strategy for sustainable development of Romania Horizons 2013-2020-2030,( adopted in 2008), overlapped, to a large extent, with the period when Romania became a member of the European Union, with all the rights and obligations it entails. Since the beginning of the accession negotiations in the EU in 2000, sustainable development has become an integral part of Romania's legislative and institutional framework, being reflected in the main directions of public policy. However, the country was severely affected by the economic and financial crash of 2008, the gross domestic product (GDP) and the level of individual incomes drastically decreasing as a result, the effects of which were felt until 2010-2011. The crisis has revealed several persistent structural and functional vulnerabilities that have necessitated a rethink of the priorities that involve mobilizing Romania's budgetary resources and using sensitive 
funds of solidarity, cohesion, agriculture and rural development, allocated to Romania through the current and future multiannual financial framework. Romania's shortcomings in the implementation of the 2008 Strategy and the specific areas in which additional efforts and resources are needed to reach the convergence objectives and to move significantly closer to the EU average are described in the following pages: (1)The strategy will put an end to poverty in all its forms everywhere. Objectively, the 2030 agenda tries to highlight to include those segments of society that have been excluded, this will help to create a more just society, where everyone can enjoy prosperity and live worthy. The strategy aims to reduce the number of citizens living in extreme and relative poverty, in all its forms, according to national definitions. The strategy aims to reduce the number of people living below the poverty line by encouraging participation in the labor market by those who are suitable to work and develop the system of social protection and assistance. The legal framework in the social services field, the prevention of social exclusion and marginalization and the promotion of inclusion are ensured through the approval of the National Strategy on social inclusion and poverty reduction 2015-2020 and the Strategic Plan for 2015-2020; approval of the National Strategy for the protection of the elderly and the Promotion of active aging for 2015-2020 and the Operational Plan for 2016-2020. (2) Stopping hunger Promoting food security and improving food and promoting sustainable agriculture. While Romania has far exceeded its problems in terms of hunger, new food challenges are emerging. Creating a healthy society requires the development of a sustainable agricultural sector and awareness of the importance of healthy eating. Romania is in sixth place in Europe when it comes to the used agricultural area, which makes agricultural efficiency and the consolidation of farms and food processing companies a priority. (3) Ensuring a bealthy life and promoting well-being for all, at all ages. It is necessary to improve access to healthcare and increase its quality, which is essential for a sustainable society. It must be built on an appropriate framework that promotes a healthy and proactive lifestyle and encourages social activities, prevention and education. (4) Ensure inclusive and fair quality education and promote lifelong learning opportunities for all. Access and participation in good quality education are essential for society to function properly and to become sustainable. Education should not just be a process that must be completed before entering the workforce. We must have the process of preparing the young generations for the challenges of the future and one that continues throughout our lives. (5) Achieving gender equality and empowering all women and girls. The gender in which it is born should not influence the opportunities, dignity or quality of life. Over $51 \%$ of the population of Romania is female and, despite some progress in the field of gender equality, there are still challenges regarding public preconceptions regarding the role of women in society and family, the involvement of women in decision making, the difference in remuneration between women and men, and violence against women. (6) Ensure the availability and sustainable management of water and sewerage for all. In order for the planet to prosper, its ecosystem, society and economy need fresh and clean water. The strategy aims to increase the quality of life by developing water and wastewater infrastructure and public services, thus bringing Romania to EU standards and requirements regarding drinking water, waste water and waste management and increasing the efficiency of water use in all sectors. Romania has a decentralized water management system. The regionalization process is almost complete and there are now 
42 regional operators outside Bucharest. (7) Ensures access to affordable, reliable, sustainable and modern energy for all. The global demand for energy is constantly increasing and only by encouraging energy efficiency and promoting renewable energy can the needs of current and future generations be met. The energy sector plays an essential role in Romania's development by profound influence on the competitiveness of its economy, quality of life and environment. (8) Promote sustainable, inclusive and sustainable economic growth, full and productive employment and decent work for all. Sustainable development encourages decoupling economic growth from the negative impact on the environment and society. (9) Build resilient infrastructure, promote inclusive and sustainable industrialization and promote innovation. Recent developments in society have resulted in a fast-paced world in which only countries that encourage innovation, resilient infrastructure and sustainable industry can compete. Sustainable industrialization means a "knowledge-based economy" based on innovation that benefits society and respects the environment. (10) Reducing inequality within and between countries. Inequality is one of the biggest obstacles to a truly sustainable society. Inequality can occur in many forms - e.g. sex, access to education and wealth, just to name a few. (11) Build human cities and settlements including, safe, resilient and sustainable. According to World Bank data, the urban population of Romania has increased from 34\% in 1960 to 54.5\% in 2014.71 According to Eurostat, in 2014, the EU average was $72.5 \%$. The urbanization process continues uninterrupted, forcing cities and towns to adapt. Urban areas must become more inclusive, safer, more resilient and more sustainable if they are to face the challenges of socio-economic and environmental change.

\subsection{The cultural Dimension of the National heritage}

The 2030 agenda for sustainable development mentions culture for the first time in the context of sustainable development objectives, both in terms of its transversal dimension and in terms of its direct dimension in the context of sustainable development of cities and communities. Smart cities an intelligent and sustainable city is innovative, using information and communication technology, data collected from the equipment used in the provision of services and intelligent planning, all under the coordination of a "smart" administration. (12) Ensure sustainable consumption and production patterns. Decoupling economic growth from environmental degradation requires a new model of sustainable consumption and production. Sustainable development requires more efficient production, more sustainable waste management and more environmental protection. Recycling is a necessity, and this requires the transition to a circular economy, while raising awareness of the limits of the planet. (13) Urgent action to combat climate change and its impact The impact of climate change, including changing climate patterns, sea level rise and extreme weather events, are being felt by Romania today. If we do not continue to implement measures to adapt and mitigate the effects of climate change, current threats, such as food security and water scarcity, may increase. (14) Conserve and sustainably use oceans, seas and marine resources for sustainable development. Marine life, climate, economy and social welfare depend on the existence of healthy seas and oceans. The strategy aims to support the prevention and reduction of marine pollution, the sustainable management and protection of marine ecosystems, the conservation of coastal areas and the practice of sustainable fishing. (15) Protect, restore and promote sustainable use of terrestrial 
ecosystems, sustainably manage forests, combat desertification, and halt and reverse land degradation and halt biodiversity loss. Romania has joined the EU with a large, valuable, and, in some cases, unique natural capital. This contribution to Europe should be recognized, appreciated and protected, including in terms of the financial sustainability of the investment required to conserve resources and maintain ecosystem services naturally to the standards set at UN and EU level. (16) Promote peaceful and inclusive societies for sustainable development, provide access to justice for all and build efficient, responsible and inclusive institutions at all levels. Sustainable development is a paradigm of the functioning of a fair society. A sustainable society is based on a strong foundation, into a stable and peaceful society in which everyone enjoys the benefits of sustainable development. The realization of such a society requires ensuring access to justice and creating efficient, responsible and inclusive legislative and institutional structures. (17) Strengthening the means of implementation and revitalizing the global partnership for sustainable development. As a member of the international community and of the European family, Romania must contribute to the joint effort to promote sustainable development, in a global world.

\subsection{Bibliographic Study}

The author Harrington, L. M. B. (2012) has the opinion: ""Sustainability" and "sustainable development" have become important concepts and goals for science and society. Sustainability, connected to desirable long-term conditions, is an activity inherently applied to geography and other fields. However, there was a lack of an integrative statement of the essential concepts on the basis of which studies and applications of sustainability are built." The author discusses ideas, theoretical concepts, including the importance of choice, place, scale, systems, boundaries, change, connected concepts, and the identity of "sustainability". The rural context is used to present examples that illustrate key ideas for sustainability, but the concepts largely apply to applications and research related to improving environmental and social change directions in local, regional and global systems under the influence of human actions. Utilitarian and human values are the focal points of sustainable development, but the single focus on them could cause irreparable losses, such as extinction of species that are not considered critical to human survival. Social scientific work can help us understand human priorities and make decisions regarding sustainability, helping to identify common values and needs for greater well-being. The concepts presented by the author, focused on the theory, are connected in the applied geography and related applications, through the need for planning, policy making, decision making and communication with stakeholders in order to be well informed and attentive to the complexity of the systems to maximize sustainability.

According to the authors Cascio, Wayne F., Ramiro Montealegre, R.,: "The relationship between new technologies, employment and inequality in recent years is the focus of attention. An important reason is the alarming reports about the possible negative consequences on employment workforce from the widespread use of new information and communication technologies (ICTs), including machine learning, production digitization, robotics and automated vehicles (Cascio, et al (2016). The pessimistic view of the impact of new technologies that represents the starting point for a brief review of the literature on employment and innovation, with an analysis of the successful creation 
and commercialization of new products and processes. In examining the existing literature, the authors are optimistic about the future: in the past, innovations were mainly favorable to the workforce; the specialized literature considers innovation and technology as the main factors of new growth and employment, at least in the long term. A number of scientific contributions show that innovation destroys, but also creates jobs.

Authors Seele, P.; Lock, I. (2017) says: "In 2015 when 193 countries agreed on 17 sustainable development goals, the delegates of the nations signed a provocative agenda aimed at restoring this planet for future generations in the next 15 years. However, efforts for sustainability have not yet resulted in greater sustainability or less unsustainability. Despite many efforts in developing and developing countries, none of the Member States of the United Nations has yet to achieve all its objectives (GeSI, 2016)." Digital technologies in the form of electronic health services, robotics or emission reduction solutions could help individuals, organizations and nations reach a more sustainable planet in the light of sustainable development goals.

The authors Strange, T., Bayley, A., (2008) are of the opinion: "Initiatives have been successfully taken at local level to raise the awareness of citizens about the importance of their participation in reducing waste production, urban renewal and other projects. In spite of all these efforts, it appeared that implementing sustainable development principles was by no means simple. "Individuals and institutions have their habits, and making them evolve can seem like an insurmountable task, even when clearly needed. The key question remains whether we have made enough progress - or taken the warnings seriously enough - to properly understand and address the most important and urgent issues. There is strong evidence that the climate is changing, and forecasts indicate a proliferation of extreme events that could have catastrophic consequences for the systems on which life is built and for human societies. Author Seghezzo, L., (2009) says: "Sustainability is usually seen as a guide for developing economic and social policies in balance with ecological conditions. More than two decades after the World Commission for Environment and Development (WCED) defined "sustainable development" and put the concept of sustainability on the global agenda, the concrete meaning of these terms and their suitability for specific cases remains contested." A new conceptual framework is needed to address sustainability issues. Sustainability could be better understood in terms of "Place", "Permanence" and "People". The place contains the three dimensions of space, Permanence is the fourth dimension of time, and the category People represents a fifth human dimension. The five-dimensional sustainability framework is probably more inclusive, more pluralistic and useful for shaping specific sustainability policies. The authors Cabiddu F. \& Pettinao, D. (2012) are of the opinion: " The study examines the relationship between the absorption capacity of an entrepreneur, the spiral of knowledge and local development." Few studies in the field have provided important evidence regarding the role of the entrepreneur's absorption capacity and external knowledge in local development. The purpose of the authors is: "to determine the possibility of contributing external knowledge and the absorption capacity of the entrepreneur, to be able to help overcome the territorial inertia that affects the local traditional knowledge. "The interpretation and analysis of the respective study explored the possibility of extracting the tacit and potential knowledge that were 
established, expressed inadequately, on a territory. The results obtained, within the time period after the organizational change, reflect an increased efficiency in monitoring the existing knowledge, of the absorption capacity of the entrepreneur, which allows the entrepreneur to discover and successfully exploit external knowledge. According to the authors, "The study supports the hypothesis that the local context can be considered a system of spatial relations which, if not supported by external knowledge, and of territorial Inertia and local development can easily attract a territory in a path of knowledge that is in contradiction with the demands of its changing environment".

In the opinion of the author (Bran, P., 2004) "natural sciences have shown that life is due to substances that we encounter at every turn. Living organisms only maintain their life if they attract and transform low entropy from the primary elements of matter: the substance, the energy, the information. Integrated into the natural circuit of matter, the living system of man is the beneficiary of a potential (low entropy), manufactured by the living and the nevi systems of Nature. Potential that allows us to exist, even if the processes we trigger in society and in the economy are very wasteful. "

In the Analytical paper Sustainable integration into the labor market, European Union, (2017)] the study stated that in the last three decades, as a result of changes in technology, work organization and the evolution of society, labor relations have become less stable and the various transitions in the labor market have become part of the working life of individuals. The problem of long-term unemployment affects half of all European unemployed. In order to solve these problems, the PES 2020 Strategy highlights the need for public employment services (PES) to act in ways that will ensure the sustainability of employing people in search of a job. This requires that PES adapts its approach to integration. The broader context of the policy to promote the sustainable integration of the labor market. The PES 2020 strategy highlights two aspects of sustainable labor market integration. The first refers to preventing the rapid recovery of unemployment, while the second refers to supporting job seekers in developing career management skills, so that they can cope with the transitions between different jobs, occupations or sectors in the future.

\section{Opportunity of Sustainable Development}

A study at national level on the current situation regarding green jobs in Romania, which addressed the issue in our country, is "Green Jobs - Creating a system for analyzing and monitoring green jobs in Romania". In this study, a documentary research was carried out to identify the initiatives regarding the transition to a green economy at national level, of the statistics available in the field, as well as of the existing measures, which are already or could be used to promote green jobs. Proposals were made regarding the possible definition of the green workplace, but also others, general as well as institutional, to contribute to the implementation of the concept of green workplace at the level of the Public Employment Services in Romania. These conclusions are grouped on the main areas of responsibility of the Public Employment Service in Romania, fields related to legislative aspects, namely: defining the green workplace, criteria for defining the green jobs, registering the green vacancies, active measures employment to promote green jobs. Measurement of production and 
employment in the green sector of the economy has also been strongly demanded by the political and legal departments that need reliable internationally harmonized statistics on green jobs to help: (I) more a good understanding of the impact of "greening the economy" on the labor market, and (II) ensuring that effective policy measures and tools are formulated to respond to this shift towards a green economy.

The development of organic farming in Romania. According to Article 29 of Regulation (EU) no. 1305/201322 [22] Organic farming promotes extensive agricultural practices, providing public environmental goods and responding to the society's demand for the use of environmentally friendly agricultural practices, but also the increased consumer demand for organic products. Organic farming practices contribute to protecting biodiversity, maintaining soil fertility and functionality, reducing pollution of water resources and improving water management, reducing carbon dioxide emissions and ensuring animal welfare conditions (low density of livestock). The Green Jobs for a Revitalized Food and Agriculture Sector 23 report presents an overview of the opportunities to create "green jobs" by encouraging and investing in implementing a global transformation of the agricultural sector into an "organic farming" paradigm, sustainable, productive and ecologically balanced. In the context of this report, "organic farming" is broadly defined as "the use of agricultural practices and technologies that simultaneously: (I) maintain and increase the productivity and profitability of the farm while ensuring the supply of food on a sustainable basis, (II) reducing externalities negative and lead gradually to the positive ones, and (III) rebuild ecological resources by reducing pollution and using resources more efficiently.

Opportunities for the development of renewable energy sources in Romania. In opinion of authors Papatulica, M., Prisecaru, P. (2013) According to the study "Dynamics of renewable energy in the EU and Romania" developed by the Romanian Academy, at present, renewable energy represents only $8.5 \%$ of the total energy used at EU level. The development of the renewable energy sector in Romania is based mainly on the following favorable premises: 1) The existence of an important and diversified theoretical potential of renewable energy sources: hydropower, technically amenable, about 32,000 GWh / year, which provides over one third ( $35.7 \%$ ) of the country's electricity production; wind power, of $14,000 \mathrm{MW}$ installed power (17\% of the total); photovoltaic (12\% of the total); biomass (of agricultural and forest origin), representing $7 \%$ of the primary energy demand and $50 \%$ of the resource potential.

Biomass as a renewable energy source, analysis of technologies for obtaining energy from it. In opinion of authors Balázsi, A.,(2013), [1] According to the Energy Conservation Agency (ARCE), Romania should encourage companies and citizens to invest in alternative energy sources, so that the share of electricity produced from renewable energy resources, compared to the national gross electricity consumption, is consistent. This type of nonpolluting energy is practically inexhaustible, in the medium and long term, its costs being much lower (by about 40\% compared to conventional energy sources), especially under the conditions in which the price of petroleum products is constantly increasing.

Sustainable transport in Romania. The strategy for sustainable transport between 2007-2013 and 2020, 2030 The initial policies included in the White Paper * of the transport policy were focused on the profitability and increase of the attractiveness of the modes of transport with great potential in terms of transport capacity and environmental protection. The 
White Paper on Transport Policy (revised in 2006) includes actions that aim to create a competitive rail network through liberalization, technological innovation and equipment interoperability, infrastructure investments and better market monitoring, smart charging, improving security and safety for different modes of transport.

Climate change policies for Romania - as an economic incentive for targeting a "green" economy the national strategy on climate change and economic growth based on low carbon emissions As a national strategic document in the field, the Strategy provides important input data for updating the National Strategy on Climate Change 2013 - 2020, covering in detail the present period until 2030 and tracing the roadmap for 2050. The strategy includes target data for 2030 and 2050 and the implications of these targets for economic growth and distribution in Romania. The sectoral debate covers the energy, transport, agriculture and rural development sectors. The objectives reflect the national priorities, determined by Romania's commitments in the field of climate change and energy and are documented through information regarding the likely social and economic costs and benefits of the policies and measures in various sectors.

Ecotourism - potential for green jobs According to the National Strategy for the development of ecotourism in Romania the development of eco-tourism activities within local communities and within protected areas implies a series of socio-economic benefits, giving priority to the creation of jobs on the plan. local (directly in the tourism sector or related sectors); stimulates the local economy by developing tourism infrastructure and services; it stimulates the rural economy by creating or increasing the demand for agricultural products needed to provide the tourist services, it promotes the development of the infrastructure, which also brings benefits to the local population, etc. important activities.

Development of the green economy in EU member countries. [27] Evolution of the main indicators in OECD member countries. The European experience of developing the green economy In the EU, the Economic Recovery Plan was approved, which envisaged the boosting of the aid of 400 billion euros in order to raise purchasing power, stimulate economic growth and create jobs. The respective plan of economic restoration provided for a series of measures, particularly to combat climate change, in the field of energy efficiency, clean technologies, to improve the professional knowledge of ecological guidance and to support the production of ecological guidance. In addition, many EU member countries have developed National Economic Recovery Plans.

Renewable energy sources. According to Eurostat (Renewable Energy Statistics) information [28] on renewable energy sources in the European Union (EU), recent information on renewable energy sources includes wind energy, solar energy (thermal, photovoltaic and concentrated), hydroelectric power, tidal energy, geothermal energy, biomass and part of renewable sources of waste. "Eco-renovation" refers to an integrated approach to community revitalization. In opinion of authors Tapper, R., Shovelton, R. (1997): „The projects cover both the natural and human dimensions of sustainable development at local level and thus generate improvements in the physical, social and economic quality of the communities. This report examines three key programs that demonstrate practical initiatives for eco-innovation, designed with the twin objectives of creating jobs and improving the environment." They were presented at a conference on "Eco-renovation Jobs and environment" in Copenhagen, in September 1995, and were developed to 
successfully meet these twins with a main focus on home renovation - involving actions on energy, waste and water - and on industrial greening - providing support for environmental improvements in small and medium-sized enterprises (SMEs). Using lessons from these three programs, the report assesses how similar a possible action might have been, and those framework factors that can locally inhibit or encourage green renovation initiatives have been replicated.

In the study of European competitiveness report 2001, Chapter V The competitiveness of European biotechnology: a case of innovation (2001). This chapter analyzes the state of innovation and production systems in European biotechnology, namely its innovative capacity and associated factors. Biotechnology cannot be considered as an industrial sector, but rather as a set of technologies developed in the field of life sciences. Its applications span a number of other industrial or service and agricultural sectors. This direct connection with science makes innovation capacity a major determinant of competitiveness.

Authors John, M., Yücel, Thompson K., Duca, John V., (2002) argue: "It is argued that it is a daunting task today to divine how biotechnology will affect future economic activity, as it would have been for economists in the 18th, 19th and 20th centuries, such as the influence of the steam engine, electricity and microchip and, ultimately, transforming the world economy". Biotechnology can change our world just as much. In conclusion, the authors claim that: "The science of life as a formal industry has existed for only a quarter of a century, but the use of living organisms to promote the quality of human life has been going on for thousands of years. Public funding accelerated the growth of life sciences and catalyzed private interest in this sector. Gains from trade between countries, transactions between private and public entities have been essential to the growth of the industry in recent years. Although it is too early to say what the overall impact of biotechnology will be, the effect of industry on the economy is already noticeable and is growing rapidly.

Author Timmis K. et al. of the study are representative or focused on several important strategic directions in their approach (1) Population growth, demographic transition and demographic dividend. A major factor that requires special attention in sustainable development strategies is the pace at which the global community has grown and is projected to grow in the foreseeable future. (2) Bio-based economy - which facilitates current and future economic growth. Creating new employment opportunities depends on a number of parameters, such as demand, capital expenditures, distribution of rents to increase productivity, and balanced growth of existing business enterprises. (3) Microbial biotechnology - exceptional diversity of applications and specialization opportunities. Microbial biotechnology is one of the oldest technologies and one of the newest and fastest growing industries. (4) Microbial biotechnology - exceptional innovation and entrepreneurial actors. The potential of application diversity does not automatically translate into commercial activities, expanding the business or increasing employment: the potential must be mined, materialized, developed, refined and marketed, all of which require talented innovators working in a favorable environment. (5) You must fuel innovation. The longterm success of an organization is determined by a series of indicators, originality and innovation are undoubtedly essential, both for the successful evolution and for the funder's / client's perception of its quality and potential. (6) Sustainability considerations will 
change the perception of the value of the application. Many biotechnology products and processes are of high value, others tend to be perceived as low value, often uncompetitive with existing raw materials and technologies, and less attractive for development and investment. (7) The increasing importance of artificial intelligence for biotechnology - changing the focus of specialization. (8) Improving the creation of bio-economic and transnational values. (9) Maintaining the return on investments in education and recruiting new talents. A potential problem for countries that do not invest in biotechnology research and creation is that aspirations can be frustrating as a brain drain - their best talents migrate and fail to return. (10) Attracting young professionals to the most dynamic sectors of biological activity (11) The proposal to support economic revival and business creation and employment through investments in microbial biotechnology has universal applicability, taking into account the mentality and adequate political determination. (12) Maintaining the return on investments in education and recruiting new talents (13) Attracting young professionals to the most dynamic sectors of biological activity.

Nanotechnology Implications for Labor Marker. In opinion of authors Invernizzi, N., Folador, G., (2010) [7] Research on the social implications of nanotechnology has hardly addressed the subject of work, despite the social importance of the subject. Based on an analysis of the characteristics of nanotechnology products that are already on the market, this article shows that nanotechnology will have a significant impact on the distribution of jobs between sectors, the international division of labor and the qualification requirements for work, causing destabilizing effects on employment. Work at national and global level. The authors describe how nanotechnology will lead to job creation and destruction, changes in the sectorial distribution of labor, changes in the global spatial distribution of labor and changes in qualifications for jobs. In recent years, research on the social implications of nanotechnology has led to a series of studies that have led to debates both within and outside the academic community.

Digitization the sustainable development. The authors Ciobanu, G., etc., ( 2015) consider: in the Romanian digital society faces a number of essential issues, but is also characterized by a good level of experts' training in this area. Considering the lag of economic development at the level of local and regional development, we belive that an important issue is to ensure the IT of the region. We will be able to develop the region if we create national and regional development networks, virtual organization of different levels and in different areas of activities. Romania must approach the hudge gap of digital competences. Romania has to develop the citizens'digital skills. The effectivency and the level of services provided by the healh systems can be significantly improved by means of digitization. Development the public modern on-line service, effeciently provided, are a means to decease public administration expenses and to increase the effeciency for both companies and citizens.

\section{Conclusion}

1. Sustainable local social and economic development in Romania requires a paradigm shift first and foremost a paradigm shift at the level of rural communities mainly, but also of urban localities. The viability of this change will be possible if local values are upheld and recognized. Human values, generator of cultural, intellectual values, of local technical and technological potential, their understanding and perception 
of the values of different social groups of people from local communities and including the ways to perceive and to prioritize social-economic and environmental problems for planning and implementing ecological renovation programs. Initiatives that are driven from the bottom up with special efforts of social involvement excluded, by national government institutions in close collaboration with the institutions of the county public administration and of the local public administrations in solving the problems of social inclusion. Developing innovative action programs to achieve objectives in creating and improving the environment, evaluating and learning new programs and projects for ecological renovation.

2. Development of programs and projects for local communities and SMEs. Develop Strategies for solving environmental degradation and unemployment problems. Finding the right people for the right programs.

3. Understanding the real needs of the target audience and creating conditions for offering flexibility in the proposed programs to meet the individual needs of local communities and SMEs.

4. Focusing on local communities, social groups of stakeholders and companies that are ready for change and understanding the problems and pressures they face from economic, financial, rural / urban, social and technological.

5. Each locality, whether rural or urban, is unique in its own way; therefore one must find that viable and functional model for their development with the real problems of each locality and possibilities for adapting the transfer of development programs.

6. The inability of SMEs to allow themselves to update aspects of operations on their own. A part of the local budgets must be allocated to the organizational aspects of the ecological renovation programs, for strategic studies, the initiation and maintenance of partnerships, advisory staff, informational communications of educational, informative and cultural character and technical assistance to the partners.

7. Training in the field of social and eco-innovation entrepreneurship, development of entrepreneurial activities on behalf of the wider community as a new activity, by identifying and training social and eco-innovative entrepreneurs. Implementation of market mechanisms that is still insufficient at the initial stage.

8.Development of new forms of social marketing, eco-innovation marketing, ecological marketing and the marketing mix of these activities and branches that are based on community oriented households and individual assistance for local SMEs; Searching for various funding sources and an in-depth evaluation.

9. Preparation of an eco-renewal and eco-innovation agenda that will deal with job creation, local economic development, solving local social problems (social assistance, social assistance etc.) and solving ecological, eco-innovation problems and development have ecological branches (organic agriculture, organic tourism, organic transport), all in a close combination. The integration of these objectives is a priority for the competitiveness and resilience of local economies and which will prove viable through competition with other localities.

10. Developing innovative and financing mechanisms with an impact of local public administration management in support of eco-innovation, eco-renewal that will drive local economic development, and will contribute to the creation of jobs for various social groups. 


\section{References}

Angheluta, S. P., Burlacu, S., Diaconu, A., \& Curea, C. S. (2019). The Energy from Renewable Sources in the European Union: Achieving the Goals. European Journal of Sustainable Development, 8(5), 57.

Balázsi, A.,(2013), Biomasa ca sursă de energie regenerabilă, analiza tehnologiilor de obținere a energiei din aceasta, http://www.urbanaodorhei.ro/dokumentumok/Informaciok/Biomasa Ro.pdf

Bodislav, A. D., Rădulescu, C. V., Moise, D., \& Burlacu, S. (2019). Environmental Policy in the Romanian Public Sector. The Bucharest University of Economic Studies Publishing House, 312.

Bran, P., (2002) Economica Valorii, Editura ASE, Bucuresti, 2002 ISBN 9735940841 Cascio, Wayne F., Ramiro Montealegre, R., (2016) How Technology Is Changing Work and Organizations Article, March 2016 DOI: 10.1146/annurev-orgpsych-041015-062352

Cabiddu \& D. Pettinao, (2012) External Knowledge, Territorial Inertia and Local Development: An Exploratory Case Study, European Planning Studies, 2012, 1-20, iFirst article, Print ISSN: 09654313 Online ISSN: 1469-5944, Print/ISSN 1469-5944,online:

Ciobanu, G., etc., (2015) Aspects of the digital economy development in Romania. Theory, measurement techniques, development policies and job generation, Ed. Universitara, ISBN 978-606-28-0266-0

Costache, G., Marinas, C. V., Igret, R., \& Burlacu, S. (2015). Internship in the Hr department-organizational and individual perspectives. In Proceedings of the International Management Conference (Vol. 9, No. 1, pp. 359-370). Faculty of Management, Academy of Economic Studies, Bucharest, Romania.

Dima, C., Burlacu, S., \& Buzoianu, O. A. C. (2020). Strategic Options for the Development of Ecotourism in the Danube Delta in the Context of Globalization. In SHS Web of Conferences (Vol. 74, p. 04005). EDP Sciences.

Harrington, L. M. B.,(2016), Sustainability theory and conceptual considerations: a review of key ideas for sustainability, and the rural context. Papers in Applied Geography. 2(4): 365-382. (doi $10.1080 / 23754931.2016 .1239222)$

Invernizzi, N., Folador,G.,(2010) Nanotechnology Implications for Labor , Invernizzi \& Foladori, Nanotechnology Implications for Labor, 7 Nanotechnology Law \& Business 68 (Spring 2010)(p.68-78)

Ionita, F., Ursacescu, M., \& Burlacu, S. (2009). Public services as poles of regional competitiveness in sustainable development. Revista de Management Comparat International/Review of International Comparative Management, 10(3), 552-565.

Ioniţă, F.; Burlacu, S. \& Gaidargi, A.(2009) Modern approaches of the management of alternative trade systems, Revista de Management Comparat International/ Review of International Comparative Management,51, 473-480

Jianu, I., Dobre, I., Bodislav, D. A., Radulescu, C. V., \& Burlacu, S. (2019). The implications of institutional specificities on the income inequalities drivers in European Union. Economic Computation and Economic Cybernetics Studies and Research, 53(2), 59-76.

John, M. , Yücel, Thompson K. , Duca, John V.,(2002) The Economic Impact of Biotechnology, Federal Reserve Bank of Dallas, Issue 2 Southwest Economy, March/April, 2002online https://www.researchgate.net/publication/5030715

Papatulica, M., Prisecaru, P. (2013) Dinamica energiilor regenerabile în UE și România,"Dynamics of renewable energy in the EU and Romania", Studii Economice, Academia Română, INCE, p.1314, http://www.studii-economice.ro/2013/seince 130220.pdf

Rădulescu, C. V., Bodislav, D. A., \& Burlacu, S. (2018). Demographic explosion and it governance in public institutions. Managerial Challenges of the Contemporary Society. Proceedings, 11(1), 18.

Rădulescu, C. V., Dobrea, R. C., \& Burlacu, S. (2018) The business management of distress situations. The 12th International Management Conference "Management Perspectives in the Digital Era" November 1st-2nd, 2018, Bucharest, Romania, 1, 741-747

Seele, P.; Lock, I., (2017): The game-changing potential of digitalization for sustainability: Possibilities, Perils, and Pathways. Sustainability Science. 12(2), 183-185 DOI: 10.1007/s11625- 017-0426-4 [14]

Seghezzo, L., (2009) The five dimensions of sustainability, Environmental politics, Vol.18,No.4,july 2009, p.539556,ISSN 0964-4016

Strange, T., Bayley, A., (2008) Le development durable, Le développement durable À la croisée de l'économie, de la société et de l'environnement, OECD Insights Sustainable Development ISBN: 9789264055766, online: www.oecd.org/editions/corrigenda 
Tapper, R., Shovelton, R., (1997) Employment and Sustainable Development, The Role of Local Environmental Initiatives in Job Creation, EUROPEAN FOUNDATION for the Improvement of Living and Working Conditions

Timmis, K., Lorenzo,V. Verstraete,W., Ramos, J.L., Danchin,A., Brüssow,H., Singh,B.K., and James Kenneth Timmis J.K., (2017) The contribution of microbial biotechnology to economic growth and employment creation, 2017 Sep; 10(5): 1137-1144., Published online 2017 Sep 4. doi: 10.1111/1751-7915.12845, https://www.ncbi.nlm.nih.gov/pmc/articles/PMC5609265/

*** ( 2001) A Sustainable Europe for a Better World: A European Union Strategy for Sustainable Development, Online : https://eur-lex.europa.eu/

*** (2011) Strategy 2020

*** (2018) Local Agenda 21 in Romania [2]

*** (2018)Romania’s Sustainable Development Strategy 2030. - Bucureşti : Paideia, 2018 ISBN 978-606-748262-1, http://dezvoltaredurabila.gov.ro/

*** (2015) Transforming our world: the 2030 Agenda for Sustainable Development,A/RES/70/1, United Nations, online: https://sustainabledevelopment.un.org/

*** (2008)National Strategy for sustainable development of Romania - Horizons 2013-2020-2030.

*** (2016) National Strategy on social inclusion and poverty reduction 2015-2020, Romania

*** (2015) National Strategy for the protection of the elderly and the Promotion of active aging for 20152020/Strategia națională pentru promovarea îmbătrânirii active şi protecția persoanelor vârstnice 2015-2020

*** (2013) Regulation (EU) no. 1305/201322, https://eur-lex.europa.eu/

*** (2014) Raport privind Analiza cadrului legislativ actual, comparativ cu cel existent la nivel european şi formularea de propuneri pentru stimularea înființării de locuri de muncă verzi în România, Activitatea 17, Bucureşti 2014, Fondul Social European, Programul Operațional Sectorial Dezvoltarea Resurselor Umane 2007 - 2013 Axa prioritară 4 „Modernizarea Serviciului Public de Ocupare”, Domeniul major de intervenție 4.1 „Întărirea capacităţii SPO pentru furnizarea serviciilor de ocupare”, Titlul proiectului: „Green Jobs - Crearea unui sistem de analiză şi monitorizare a locurilor de muncă verzi în România", Contract POSDRU/111/4.1/S/91801

*** (2008) The strategy for sustainable transport between 2007-2013 and 2020, 2030 / Strategia pentru transport durabil pe perioada 2007-2013 şi 2020, 2030

*** (2013) The National Strategy on Climate Change 2013 - 2020 / Strategia naţională a României privind schimbările climatice 2013 - 2020

*** (2013) Strategia națională de dezvoltare a ecoturismului în România, Bucureşti, septembrie 2009,p. 5/ National Strategy for the development of ecotourism in Romania, http://turism.gov.ro/

*** (2014) Economia verde și locurile de muncă verzi. Dezvoltarea conceptului de locuri de muncă verzi la nivel international, realizat prin proiectul "GREEN JOBS-Crearea unui system de analiză şi monitorizare a locurilor de muncă verzi în România", http://proiect.locuridemuncaverzi.ro/

*** Eurostat (Renewable Energy Statistics) information on renewable energy sources in the European Union (EU).

*** Comisia Naţională de Strategie și Prognoză http://www.cnp.ro/

***Institutul National de Statistica www.insse.ro

*** (2001), European competitiveness report 2001, Chapter V The competitiveness of European biotechnology: a case of innovation, https://ec.europa.eu/

***(2017)Sustainable integration into the labour market,Analitical paper,Luxembourg: Publications Office of the European Union, 2017, ISBN 978-92-79-66254-6 doi:10.2767/241832 